DE DE GRUYTER

OPEN

UDK: 336.748.12(4-12)

DOI: $10.1515 / j c b t p-2016-0007$

Journal of Central Banking Theory and Practice, 2016, 1, pp. 141-157

Received: 29 July 2015; accepted: 25 August 2015

Mico Apostolov ${ }^{*}$, Dusko Josevski ${ }^{* *}$

\title{
Aggregate Demand-Inflation Adjustment Model Applied to Southeast European Economies
}

\begin{abstract}
Applying IS-MP-IA model and the Taylor rule to selected Southeast European economies (Albania, Bosnia and Herzegovina, Macedonia and Serbia) we find that the change of effective exchange rate positively affects output, while the change of the world interest rate negatively affects output or it does not affect the output at all, and additional world output would help to increase output of the selected economies.
\end{abstract}

A lower ratio of government consumption spending to GDP would also increase the output of the selected economies. Hence, fiscal prudence is needed, and the conventional approach of real depreciation to stimulate exports and raise real output does not apply to the selected Southeast Europe economies.

When private household consumption is employed in the model, the coefficient on government spending to nominal GDP is insignificant implying that Ricardian equivalence does hold for the selected countries.

JEL Classifications: D05; E05; F04; G28; H05; P02

Keywords: IS-MP-IA, Taylor Rule, inflation targeting, monetary policy function, government spending to nominal GDP, world interest rates

\section{Introduction}

David Romer (Romer 2000) proposed an alternative to the IS-LM model and AS-AD model. This model makes assumption that central banks in the world 
follow interest rate rule rather than targeting money supply. Hence, the model is also known as AD-IA or aggregate demand inflation adjustments model. The assumption is identified as monetary policy rule (MPR) based on the Taylor rule (Taylor 1993), where the federal reserve (central bank) increases interest rates in response to inflation increase (and vice versa):

$$
\mathrm{i}_{\mathrm{t}}=2+\pi_{\mathrm{t}}+\gamma\left(\pi_{\mathrm{t}}-\pi_{\mathrm{t}}^{*}\right)+\vartheta\left(\mathrm{y}_{\mathrm{t}}-\mathrm{y}_{\mathrm{t}}^{*}\right)
$$

where $i_{t}$ is the prescribed interest rate in the period $t ; \pi_{t}$ is the actual inflation rate; $\pi_{t}-\pi_{t}^{*}$ is the deviation of actual inflation from its target rate $\pi_{t}^{*}$; and $y_{t} y_{t}^{*}$ is the deviation of actual output to its potential output (output gap). In the expression, $\gamma>0 ; \vartheta>0$. The assumption that central banks follow an interest rate rule is far more realistic than the hypothesis that central banks target money supply. Romer's approach claims that aggregate demand relates to output and inflation, thus target rate equals the last period inflation $\pi_{t}^{*}=\pi_{t-1}$ (Romer 2000). In turn, it also denotes that inflation rises when output is above its own natural rate, and inflation falls when output is below its natural rate.

We apply this model to Southeast European countries, namely Albania, Bosnia and Herzegovina, Macedonia, and Serbia. Albanian economic policy in the previous two decades aimed at maintaining macroeconomic stability and noninflationary policies and achieving fiscal consolidation through public debt reduction (Korovilas 1999). As a consequence, Albania reduced its budget deficit for the 2010 to $3.2 \%$ of GDP, where previously in 1990's budget deficit was $9.6 \%$ (Shijaku and Gjokuta 2013). Fiscal policy has been more prudent over the past 20 years and, as a result, total public debt to GDP ratio has shown a declining trend from $35 \%$ in 1990 's to $29 \%$ in 2010 . The current expenditures to GDP ratio have also diminished from $29 \%$ in 1990 's to $24 \%$ in 2010. As far as the exchange rate is concerned, as one of the most important macroeconomic variables, Albania opted for flexible exchange rate regime in the beginning of the transition process (Bitzenis and Nito 2005). Rationale for this decision was to avoid costly adjustments of possible exchange rate misalignments that usually characterize pegged rate regimes (Vika and Luçi 2011).

Bosnia and Herzegovina is a small open economy and due to the troublesome past its GDP reduced from 10.7 US billion dollars in 1992 to 3.2 US billion dollars in 1996 (Thomas and Bojicic-Dzelilovic 2014). As of 2000, the country has been gradually increasing its own GDP per capita three fold. The fiscal policy is the only active segment of Bosnia's macroeconomic policy. Additionally, the 
exchange rate and interest rate are passive instruments ${ }^{1}$, and money supply is determined by 'currency board' (Dell'Anno and Piirisild 2007). Indeed, the only monetary instrument which is available to the Central bank of Bosnia and Herzegovina and is established by the currency board is required reserves ratio, thus the bank cannot influence the interest rates and the money supply. Bosnia and Herzegovina had an average budget surplus of 2.2\% of GDP for the period 20032005 , but also had highest public spending that averaged $44.7 \%$ of GDP, i.e. $18 \%$ above from the regional average.

The National Bank of the Republic of Macedonia aims at price stability, low and stable inflation (Petkovski and Slaveski 1997; Slaveski 1997). Its operational targets are interest rates and liquidity, whereas the intermediate target is the exchange rate through which the central bank affects price stability (Besimi, Pugh et al. 2006; Apostolov 2011). The exchange rate in Macedonia is fixed, and the Balassa-Samuelson effect indicates that the process of catching up with the level of productivity will cause a higher inflation rate and, as it is currently the case, if there is a fixed exchange rate, it will spike real appreciation of the domestic currency.

The case of Serbia is a peculiar one as it also suffered from a series of political turmoil where over the past decades it has had experienced macroeconomic policy but wobbly political instability. Unfortunately, Serbia has not been able to achieve one-digit rate of inflation, which is a key indicator for macroeconomic stability. Public spending to GDP was $43.6 \%$ of GDP in 2009. This is due to increased revenues from privatization which lead to larger government spending (Gros 2002; Bićanić, Kukavčić et al. 2010). The fiscal deficit has increased from $-0.9 \%$ to $-4.2 \%$. Core purpose of central bank is to provide monetary and financial stability, which means a stable financial system (Staikouras, Mamatzakis et al. 2008). The National bank of Serbia manages interest rates in order to provide a low and stable inflation rate, protect the citizen's living standard, and manages foreign exchange reserves.

\section{Interest rate consumption income and savings}

A representative consumer maximizes is defined as:

$$
\int_{0}^{\infty} \mathrm{u}[\mathrm{c}(\mathrm{t})] \mathrm{e}^{-\delta \mathrm{t}} \mathrm{dt}
$$

\footnotetext{
1 Exchange rate in Bosnia and Herzegovina is determined by hard peg.
} 
and it is a subject to:

$\dot{\mathrm{a}}=\mathrm{y}+\mathrm{ra}-\mathrm{c}$

$\mathrm{a}(0)$ is given where $\mathrm{y}$ is rare constant through time, $\mathrm{y}$ is perishable output, and a represents a stock of interest-bearing real financial assets. We do not necessarily impose that the subjective discount rate $\delta$ is equal to the market real interest rate r. A no-Ponzi condition also is imposed on the problem (Bergman 2001; SchmittGrohé and Uribe 2003; Tamegawa 2013). This means that for a consumer with a market discount factor $\rho_{\mathrm{t}}$ we have the following budget constraint:

$B_{t} \leq E_{t} \sum_{s=1}^{\infty} \beta^{s} \frac{\rho_{t+s}}{\rho_{t}}\left(Y_{t+s}-C_{t+s}\right)$

This corresponds to a period budget constraint and no-Ponzi condition:

$C_{t} \leq Y_{t}-\beta^{-1} \rho_{t}^{-1} B_{t-1}+B_{t}$

$\lim _{T \rightarrow \infty} E_{t}\left[\beta^{T} \rho_{t+T} B_{t+T}\right]$

For the isoelastic function we have:

$\mathrm{u}(\mathrm{c})=\frac{\mathrm{c}^{1-\frac{1}{\sigma}}-1}{1-\frac{1}{\sigma}}$

$\mathrm{y}$ and $\mathrm{r}$ are constant through time.

Hamiltonian for this problem is:

$\mathrm{H}=\mathrm{u}(\mathrm{c})+\lambda(\mathrm{y}+\mathrm{ra}-\mathrm{c})$

First order conditions are:

$\frac{\partial \mathrm{H}}{\partial \mathrm{c}}=\mathrm{u}^{\prime}(\mathrm{c})-\lambda=0$

$\dot{\lambda}=\lambda \delta-\frac{\partial \mathrm{H}}{\partial \mathrm{c}}=\lambda(\delta-\mathrm{r})$

$0=\lim _{\mathrm{t} \rightarrow \infty} \mathrm{e}^{-\delta \mathrm{t}} \lambda(\mathrm{t}) \mathrm{a}(\mathrm{t})$

First derivative of consumption is:

$\mathrm{u}^{\prime}(\mathrm{c})=\mathrm{c}^{-1 / \sigma}$

The last equation can be written as: 
$\mathrm{u}^{\prime \prime}(\mathrm{c}) \dot{\mathrm{c}}=\mathrm{u}^{\prime}(\mathrm{c})(\delta-\mathrm{r})$

or as:

$\frac{\dot{c}}{c}=\frac{-u^{\prime}(c)}{c u^{\prime \prime}(c)}(\delta-r)=\sigma(r-\delta)$

The solution for linear differential equation describing consumption path is:

$c(t)=c(0) e^{\sigma(r-\delta) t}$

integrating a( 0 ) and imposing no-Ponzi condition preventing unlimited debt, the intertemporal budget constraint is :

$\mathrm{a}(0)=\int_{0}^{\infty}[\mathrm{c}(\mathrm{t})-\mathrm{y}] \mathrm{e}^{-\mathrm{rt}} \mathrm{dt}$

if we substitute the equation for $\mathrm{c}(\mathrm{t})$ in the last equation than we need to solve the equation:

$$
\begin{aligned}
\mathrm{a}(0) & =\int_{0}^{\infty}\left[\mathrm{c}(0) \mathrm{e}^{\sigma(\mathrm{r}-\delta) \mathrm{t}}-\mathrm{y}\right] \mathrm{e}^{-\mathrm{rt}} \mathrm{dt} \\
\mathrm{c}(0) & =\frac{\mathrm{a}(0)+\left(\frac{\mathrm{y}}{\mathrm{r}}\right)}{\int_{0}^{\infty}\left[\mathrm{e}^{\sigma(\mathrm{r}-\delta) \mathrm{t}}\right] \mathrm{e}^{-\mathrm{rt} d \mathrm{dt}}}=\frac{\mathrm{a}(0)+\left(\frac{\mathrm{y}}{\mathrm{r}}\right)}{\int_{0}^{\infty} \mathrm{e}^{\sigma(\mathrm{r}-\delta) \mathrm{t}-\mathrm{rt} d \mathrm{dt}}}=\frac{\mathrm{a}(0)+\left(\frac{\mathrm{y}}{\mathrm{r}}\right)}{[\sigma(\mathrm{r}-\delta)-\mathrm{t}]^{-1}\left\{\left.\mathrm{e}^{[\sigma(\mathrm{r}-\delta) \mathrm{t}-\mathrm{r}] \mathrm{t}}\right|_{0} ^{\infty}\right\}} \\
& =[\sigma \delta-(\sigma-1) \mathrm{r}]\left[\mathrm{a}(0)+\left(\frac{\mathrm{y}}{\mathrm{r}}\right)\right]
\end{aligned}
$$

the assumption that $(\sigma-1) \mathrm{r}-\sigma \delta=\sigma(\mathrm{r}-\delta)<0, \lim _{\mathrm{t} \rightarrow \infty} \mathrm{e}^{[\sigma(\mathrm{r}-\delta) \mathrm{t}-\mathrm{r}] \mathrm{t}}=0$

Looking at the preceding consumption function, we see the three ways how a rise in the interest rate $r$ will affect saving - the marginal propensity to consume out of total wealth is $\sigma \delta-(\sigma-1) \mathrm{r}$. When $\mathrm{r}$ rises, that coefficient falls with an effect proportional to $\sigma$. This is the substitution effect. The substitution effect is counteracted by an effect proportional to unity that tends to make $\sigma \delta-(\sigma-1) \mathrm{r}$ to rise when $\mathrm{r}$ rises. This is the income effect. The coefficient $(\sigma-1)$ in the marginal propensity $\sigma \delta-(\sigma-1) \mathrm{r}$ captures the balance between the substitution and income effects. In addition, $y / r$ falls when $r$ rises - there is a fall in lifetime wealth and so consumption falls. This is the wealth effect.

\section{The mathematical model}

As in the works of Romer (Taylor 2000; Taylor 2001; Romer 2006), let's suppose that aggregate demand spending is determined by the real output, real interest rate, government spending and government tax revenue, i.e.: 
$E=E\left(Y, i-\pi^{e}, G, T\right)$

where $\mathrm{E}$-denotes expenditures; $\mathrm{Y}$ is expected value of the real output; $\pi^{\mathrm{e}}$ is the real interest rate which is derived when from the nominal interest rate is subtracted expected inflation ${ }^{2}$; and $\mathrm{G}$ aggregate expenditures are function of government spending financed by the taxes $(\mathrm{T})$.

The planned real expenditure is presented as:

$E=C(Y-T)+I\left(i-\pi^{e}\right)+G$

where $\mathrm{C}$ is a consumption function, $\mathrm{I}$ is investment. Shown in a Keynesian cross of equilibrium (Snowdon and Vane 2005), the planned expenditure equals the actual expenditure:

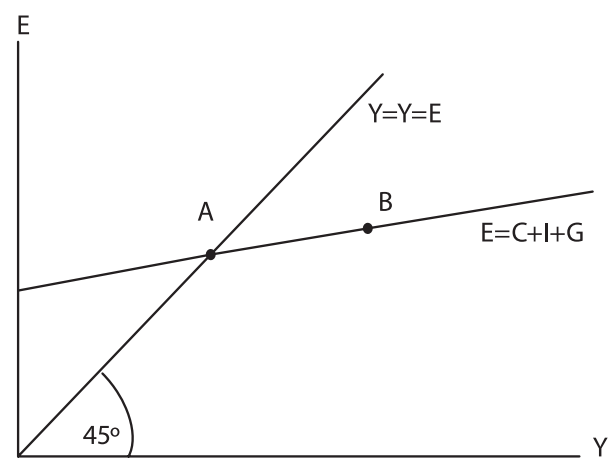

So, if $\mathbf{E}=\mathbf{Y}$ than we can rewrite the first expression as:

$Y=E\left(Y, R-\pi^{e}, G, T\right)$

The extended monetary policy function can be presented as:

$R=R\left(\pi-\pi^{e}, Y-\bar{Y}, E R-E R^{e}, \mathrm{i}^{\mathrm{W}}\right)$

where, in extended monetary policy model, $\pi^{\mathrm{e}}$ is targeted inflation or equilibrium inflation; $\bar{Y}$ is the potential output or trend output; $E R^{e}$ is expected exchange rate or lagged real exchange rate; and $i^{\mathrm{W}}$ is world interest rate. For the inflation adjustment we have:

$\pi=\pi^{e}+\alpha(Y-\bar{Y})+E R^{n o \min a l}$

2 Expected inflation one can derive by lagging inflation variable once. 
where inflation equals targeted inflation + output gap + nominal exchange rate, and its increase means appreciation. Further, the real effective exchange rate model states that:

$E R=f\left(i-i^{\mathrm{W}}, E R^{e}\right)$

So, real effective exchange rate is a function of real interest rate minus world interest rate and expected exchange rate, i.e. lagged exchange rate. This is known as IS-MP-IA model originating in the work of David Romer (Romer 2000).

\section{From mathematical to econometric model}

The econometric model that is being estimated in this paper in its general form is presented as:

$\log Y_{i t}=\log G Y_{i t}+\log E R_{i t}^{e}+\log R^{W}+\log Y^{W}+\log \pi_{i t}^{e}+\log P O P_{i t}+$

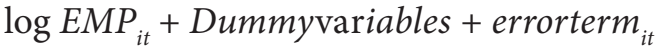

where:

- $\log Y_{i t}$ is logarithm of the output (real GDP where 2005=100, billions of US dollars from 2005 as base),

- $\log G Y_{i t}$ is ratio of government consumption spending,

- $\log E R_{i t}^{e}$ is effective real exchange rate based on a trade weighted measure, presented in the regression in its lagged form,

- $\log R^{W}$ is the world interest rate,

- $\log Y^{W}$ is logarithm of the world output,

- $\log \pi_{i t}^{e}$ is logarithm of expected inflation,

- $\log P O P_{i t}$ is the logarithm of population,

- $\log E M P_{i t}$ is logarithm of employment,

- and Dummy variables are D1=1 if sample covered is from 1969-1980, otherwise 0; D2=1 if sample covered in the regression is 1981-1990,otherwise 0; D3 $=1$ if sample covered in the regression is 1991-2001,otherwise 0; and D3=1 if sample covered in the regression is 2001-2013, otherwise 0 .

The ratio of logarithm of government consumption spending to nominal GDP $\left(\log G Y_{i t}\right)$ is used as a proxy for fiscal policy. The effective real exchange rate is based on a trade weighted measure, and here is presented in the regression in its lagged form $\log E R_{i t}^{e}, \log \pi_{i t}^{e}$ is logarithm of expected inflation. Expected inflation is also inflation at $\mathrm{Lag}=1$. Expected inflation is used as a proxy for inflation adjust- 
ment in the model. $\log R^{W}$ is the world interest rate, this variable is in the model because of its influence on the monetary policy of the selected countries. World interest rate is derived when US Federal funds rate is subtracted by the Producer Price Index in US manufacturing, which proxies for US inflation. This variable proxy for monetary policy conditions, same as exchange rate does; $\log P O P_{i t}$ and $\log E M P$ variables serve as proxies for macroeconomic conditions; $\log P O P_{i t}$ is the logarithm of population in the selected countries, while log EMP is the logarithm of employment in the selected countries, and these variables are genuinely measured in millions and thousand persons respectively. Dummy variables serve to see whether macroeconomic policies and macroeconomic conditions differed throughout 1970s, 1980s, 1990s, and from 2001 to 2013.

\section{Data and methodology}

In this paper, data for 4 countries are being used: Albania, Bosnia and Herzegovina, Macedonia, and Serbia. Data covers period from 1969 to 2013. Sources of the data are: World Bank development indicators, International financial statistics of IMF, and Oxford economic forecasting. All of the data are converted to a 2005 base year ${ }^{3}$. Data on US federal funds rate and US Producer Price Index for all commodities (which served for world interest rate derivation) are obtained by the FRED (Federal Reserve Bank of St.Louis) data base ${ }^{4}$. Constructed data base consists of 180 observations, for 4 countries. Panel is strongly balanced. This means that each panel contains exactly the same time points, i.e. $T_{i j}=T$, where $\mathrm{T}$ is the number of observations per panel. The main model was tested for serial correlation by using Wooldridge test, and the result proved that there is very small probability of making type I error if we reject the null hypothesis, no first-order autocorrelation $^{5}$. Results from the test are presented in Appendix 1. If there is no presence of autocorrelation, we can use OLS to obtain estimates; otherwise we use Prais-Winsten estimation (Egger 2002). Using this technique to eliminate serial correlation, we multiply the equation $y_{i t}=a_{i}+\beta_{1} X_{i t}+u_{i t}$ by $\left(1-\rho^{2}\right)^{1 / 2}$, and it is because $\sigma_{u}^{2}=\operatorname{var}\left(u_{i t}\right)=\sigma_{e}^{2} /\left(1-\rho^{2}\right)$ and so the result is:

$y_{i t}\left(1-\rho^{2}\right)^{1 / 2}=\left(1-\rho^{2}\right)^{1 / 2} a_{i}+\beta_{1}\left(1-\rho^{2}\right)^{1 / 2} X_{i t}+\left(1-\rho^{2}\right)^{1 / 2} u_{i t}$

when there are more than two periods in the panel we use:

\footnotetext{
3 ERS International Macroeconomic Data Set

4 Data on PPI are obtained also by U.S. Department of Labor: Bureau of labor statistics

5 Probability of making type I error was only 0.0059
} 
$y_{i t-1}=a_{i}+\beta_{1} X_{i t-1}+u_{i t-1}$

$y_{i t}=a_{i}+\beta_{1} X_{i t}+u_{i t}$

if multiplied by $\rho$, the first equation and subtract first from second equation, the result is:

$y_{i t}-\rho y_{i t-1}=(1-\rho) a_{i}+\beta_{1}\left(X_{i t}-\rho X_{i t-1}\right)+\varepsilon_{i t}, t \geq 2$

because $\varepsilon_{i t}=u_{i t}-\rho u_{i t-1}$, we get:

$\tilde{y}_{i t}=(1-\rho) a_{i}+\beta_{1} \tilde{X}_{i t}+\varepsilon_{i t}, t \geq 2$

Additionally, in Appendix 2 graphs are shown to depict the most important variables.

\section{Econometric results}

In this section results from econometric estimations are presented. Dependent variable is logarithm of output, Real GDP in 2005 US dollars. In Table 1 can be seen the result form the estimation of the first model that takes in account all of the observations, i.e. takes observations from 1969 to 2013. In the next 4 models decadal dummies control for different decades; D1 controls for period from 1969 to 1980 , D2 controls for period from 1981 to 1990 , D3 controls for the 1990s decade , i.e. for period from 1991 to 2001. And finally the model augmented with the dummy variable D4 controls for period from 2001 to 2013. 
Table 1: Estimated Regression of $\log (\mathrm{Y})$ for 4 countries: Albania, Bosnia and Herzegovina, Macedonia, and Serbia: 1969-2013

\begin{tabular}{|c|c|c|}
\hline $\begin{array}{l}\text { Dependent variable } \log \mathrm{Y}_{\text {it' }} \\
\text { Log of country's output }\end{array}$ & Variable description & Coefficient \\
\hline $\operatorname{logGY}{ }_{i t}$ & Government consumption spending to GDP & $-0.0002^{* * *}$ \\
\hline $\log E R_{i t}^{e}$ & expected exchange rate, log & $0.1007^{* * *}$ \\
\hline $\mathrm{R}^{\mathrm{W}}$ & World interest rate & $-0.0148^{* * *}$ \\
\hline$Y^{w}$ & World output, log & $0.5186^{* * *}$ \\
\hline $\log \pi_{i t}^{\mathrm{e}}$ & expected inflation, log & $-0.0556^{* * *}$ \\
\hline $\log W_{i t}$ & $\begin{array}{l}\text { Gross fixed capital formation, i.e. country's } \\
\text { wealth }\end{array}$ & $1.13 e-06^{* * *}$ \\
\hline $\log P O P_{i t}$ & Population, log & $0.1915^{* * *}$ \\
\hline $\log \mathrm{EMP}_{\text {it }}$ & Employment, log & $-0.0928^{* * *}$ \\
\hline C & Constant & $-4.0168^{* * *}$ \\
\hline R-squared & & 0.5233 \\
\hline Wald chi2(8) & & 0.0000 \\
\hline
\end{tabular}

Note: *** statistical significance at all levels of significance; ${ }^{* *}$ statistical significance at $5 \%,{ }^{*}$ statistical significance at $10 \%$.

From Table 1 we can see that (for the whole time period 1969-2013) government consumption in relation to nominal GDP does negatively and statistically significantly. In the first model all of the coefficients are significant at $1 \%, 5 \%$, and $10 \%$ levels of significance, i.e. all of the coefficients are significant at all levels of statistical significance. Table 1 presents estimated coefficients, t-statistics, $\mathrm{R}^{2}$, and other related statistics. The equilibrium Real GDP is positively associated with the appreciation of expected real effective exchange rate coefficient (0.1007), and this coefficient is significant at all levels of statistical significance. Also positive and statistically significant relationship exists between world output and output of the countries analysed in the panel. Logarithm of the expected inflation is negatively associated with equilibrium output of the countries, the coefficient is -0.0556 and it is statistically significant at all levels. Gross fixed capital formation which proxies for country's wealth i.e. productive and non-productive capacities of the country, is positively associated with the output though coefficient is of very small size (1.13e-06). World interest rate does have negative and statistically significant influence and enters in relationship with the equilibrium output.

The conventional wisdom to devalue a currency to stimulate net exports and aggregate expenditures would not apply to these 4 countries. Instead, appreciation of real effective exchange rate will increase output of these countries. 
Without a doubt, a higher world interest rate would reduce Real GDP of countries in the panel, because their national banks would respond positively to higher world interest rate by raising their monetary policy rate. Inflation would reduce Real GDP of the selected countries mainly because the national banks would raise real interest rates in order to pursue inflation targets. Increase in the logarithm of population would increase output, while increase in employment would reduce real GDP.

Table 2: Estimated Regression of $\log (Y)$ for 4 countries: Albania, Bosnia and Herzegovina, Macedonia, and Serbia: 1969-1980

\begin{tabular}{|c|c|c|c|c|c|}
\hline Model & & 1. & 2. & 3. & 4. \\
\hline $\begin{array}{l}\text { Dependent variable } \\
\log _{\text {it' }} \text { Log of } \\
\text { country's output }\end{array}$ & $\begin{array}{l}\text { Variable } \\
\text { description }\end{array}$ & Coefficient & Coefficient & Coefficient & Coefficient \\
\hline $\log G Y_{i t}$ & $\begin{array}{l}\text { Government } \\
\text { consumption } \\
\text { spending to GDP }\end{array}$ & $-0.00015^{* * *}$ & $-0.00017^{* * *}$ & $-0.0002^{* * *}$ & $-0.00017^{* * *}$ \\
\hline $\log E R_{i t}^{e}$ & $\begin{array}{l}\text { expected exchange } \\
\text { rate, log }\end{array}$ & $0.105^{* * *}$ & $0.0967^{* * *}$ & $0.149^{* * *}$ & $0.11^{* * *}$ \\
\hline $\mathrm{R}^{\mathrm{W}}$ & World interest rate & -0.001 & $-0.0139^{*}$ & -0.007 & -0.01 \\
\hline$Y^{\mathrm{W}}$ & World output, log & $1.127^{* * *}$ & $0.5376^{* * *}$ & 0.250 & 0.09 \\
\hline $\log \pi^{\mathrm{e}}{ }_{\mathrm{it}}$ & $\begin{array}{l}\text { expected inflation } \\
\text {,log }\end{array}$ & $-0.073^{* * *}$ & $-0.0573^{* * *}$ & $-0.050^{* * *}$ & $-0.06^{* * *}$ \\
\hline $\log _{\text {it }}$ & $\begin{array}{l}\text { Gross fixed capital } \\
\text { formation, i.e. } \\
\text { country's wealth }\end{array}$ & $9.58 \mathrm{E}-07^{* * *}$ & $1.15 \mathrm{E}-06^{* * *}$ & 4.94E-07 & $8.07 \mathrm{E}-07^{* * *}$ \\
\hline $\log P O P$ & Population, log & $0.2491^{* * *}$ & $0.189^{* * *}$ & $0.300^{* * *}$ & $0.244^{* * *}$ \\
\hline $\log \mathrm{EMP}_{\mathrm{jt}}$ & Employment, log & $-0.1242^{* * *}$ & $-0.096^{* * *}$ & $-0.085^{* * *}$ & $-0.099^{* * *}$ \\
\hline D1 & $\begin{array}{l}\text { Dummy variable }=1 \\
\text { if years in the sample } \\
\text { range from 1969-1980 }\end{array}$ & $0.6442^{* * *}$ & - & - & - \\
\hline D2 & $\begin{array}{l}\text { Dummy variable }=1 \\
\text { if years in the sample } \\
\text { range from 1981-1990 }\end{array}$ & - & -0.039 & - & - \\
\hline D3 & $\begin{array}{l}\text { Dummy variable }=1 \\
\text { if years in the sample } \\
\text { range from 1991-2001 }\end{array}$ & - & - & $-0.35^{* * *}$ & - \\
\hline D4 & $\begin{array}{l}\text { Dummy variable }=1 \\
\text { if years in the sample } \\
\text { range from 2001-2013 }\end{array}$ & - & - & - & $0.352^{* * *}$ \\
\hline $\mathrm{C}$ & Constant & $-10.53^{* * *}$ & $-4.175^{* *}$ & $-1.620^{* * *}$ & 0.161 \\
\hline R-squared & & 0.5573 & 0.5235 & 0.5578 & 0.5410 \\
\hline Wald chi2 (8) & & 0.000 & 0.000 & 0.000 & 0.000 \\
\hline
\end{tabular}

Note : ${ }^{* * *}$ statistical significance at all levels of significance; ${ }^{* *}$ statistical significance at $5 \%$, ${ }^{*}$ statistical significance at $10 \%$. 
Table 3: Estimated Regression of $\log (\mathrm{Y})$ for 4 countries: Albania, Bosnia and Herzegovina, Macedonia, and Serbia: 1969-2013

\begin{tabular}{lll}
\hline $\begin{array}{l}\text { Dependent variable logY } \\
\text { Log of country's output }\end{array}$ & Variable description & Coefficient \\
\hline $\operatorname{logGY}_{\text {it }}$ & Government consumption spending to GDP & -0.009 \\
$\log \mathrm{R}_{\text {e }}$ & expected exchange rate, log & $0.092^{* * *}$ \\
$\mathrm{R}^{\mathrm{w}}$ & World interest rate & $-0.015^{* * *}$ \\
$\mathrm{Y}^{\mathrm{w}}$ & World output, log & 0.397 \\
$\log \pi^{\mathrm{e}}$ & expected inflation, log & -0.074 \\
$\log \mathrm{W}_{\text {it }}$ & Gross fixed capital formation, i.e. country's wealth & $6.57 \mathrm{E}-07^{* * *}$ \\
$\operatorname{logPOP}$ & $0.281^{* * *}$ \\
$\operatorname{logEMP}$ & Population, log & $-0.074^{*}$ \\
Log C $_{\text {it }}$ & Employment, log & $0.041^{*}$ \\
$\mathrm{C}$ & Logarithm of household consumption & -3.422 \\
\hline $\mathrm{R}$-squared & Constant & 0.5428 \\
Wald chi2(8) & & 0.000 \\
\hline \hline
\end{tabular}

Note: ${ }^{* * *}$ statistical significance at all levels of significance; ${ }^{* *}$ statistical significance at $5 \%$, ${ }^{*}$ statistical significance at $10 \%$.

In presence of logarithm of household consumption, government consumption spending to GDP is insignificant. Insignificance of this coefficient may suggest that Ricardian equivalence hypothesis (Barro 1976; Buchanan 1976; Seater 1993) may be applicable to the four countries in the panel. In presence of consumption, world output and expected inflation does not influence the dependent variable, i.e. their influence is statistically insignificant. World interest rate does have negative and statistically significant influence on the output.

\section{Summary and conclusions}

This paper has examined the short term output fluctuations of major macroeconomic variables. The estimation results suggest that the change of the effective exchange rate affects output positively, while the change of the world interest rate affects output negatively or it does not affect the output at all, i.e. that variable is insignificant.

Indeed, the results also point that relatively low world real interest rates and expected world economic recovery would help increase real GDP, whereas expected real depreciation of national currencies of countries in the panel would have negative effect on the real GDP. 
The ratio of government deficit to nominal GDP should be below $3 \%$ to meet the EU convergence criterion. These countries are not yet members of the EU but they may become in some foreseeable future and they will have to fulfil the debt to GDP ratio criterion, as well as the inflation target ranging between $2.5 \%$ and $4.5 \%$. 


\section{APPENDICES}

\section{Appendix 1}

Wooldridge test for autocorrelation in panel data

H0: no first-order autocorrelation

$\mathrm{F}(1,3)=49.655$

Prob $>$ F $=0.0059$

\section{Appendix 2}

\section{Logarithm of world output $(2005=100)$}

logarithm of World output in billions of dollars; $(2005=100)$

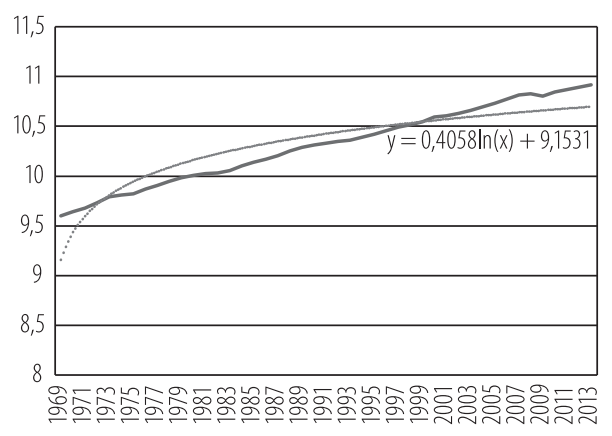

\section{Logarithm of world capital formation}
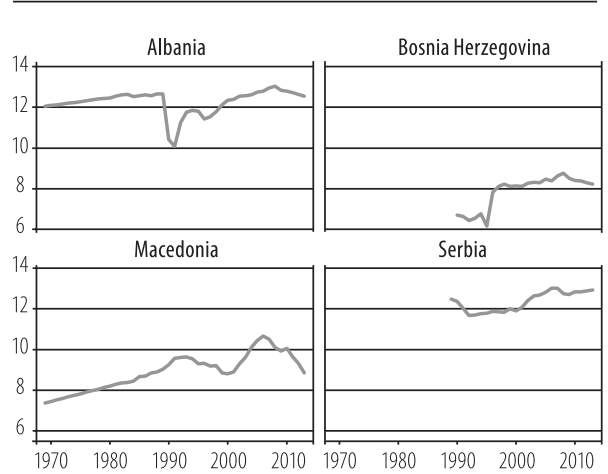

Graphs by Country

\section{Logarithm of world interest rate}

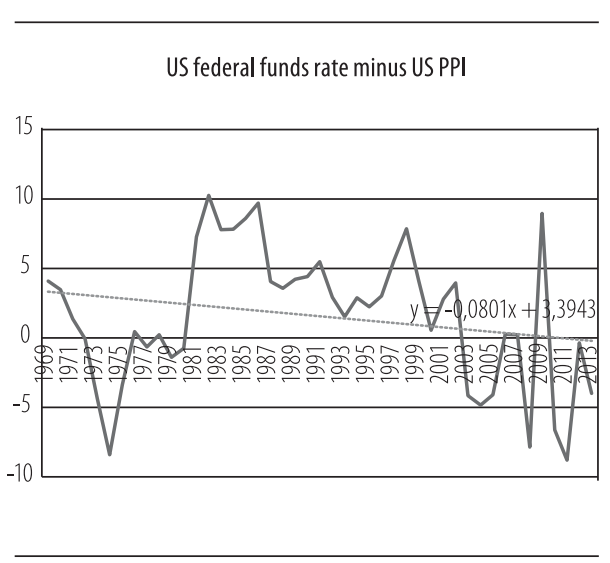

Log. of gov. spending to nominal GDP

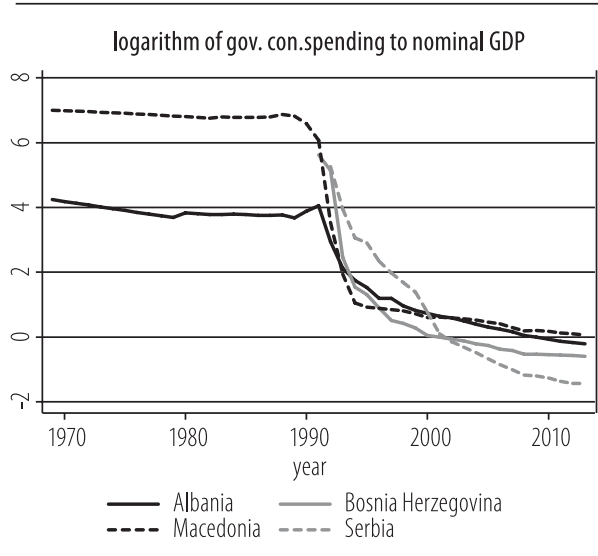




\section{Natural (trend) and actual output plots}
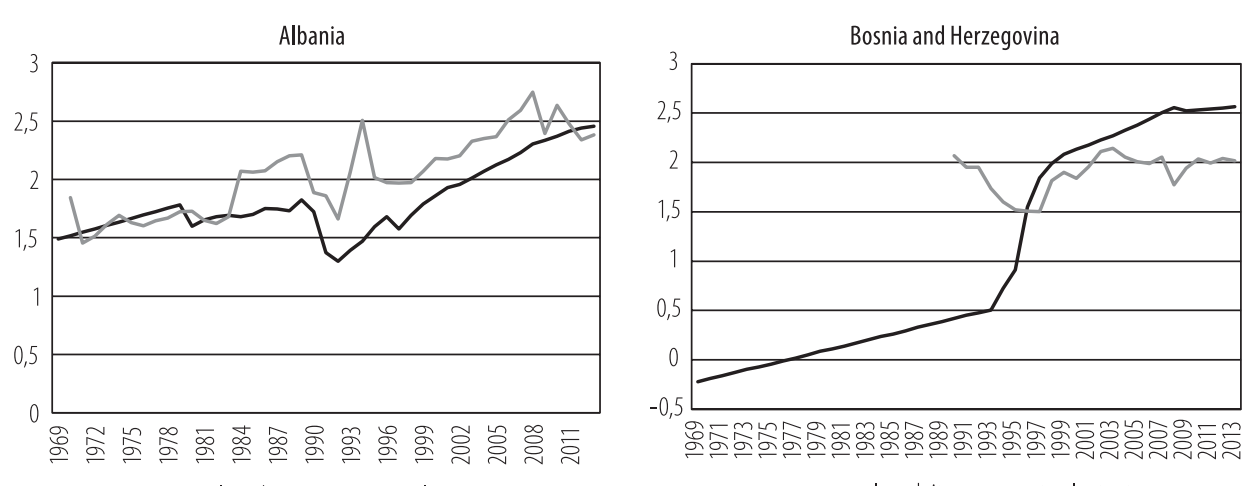

- loggdpit naturaloutput

— loggdpit naturaloutput
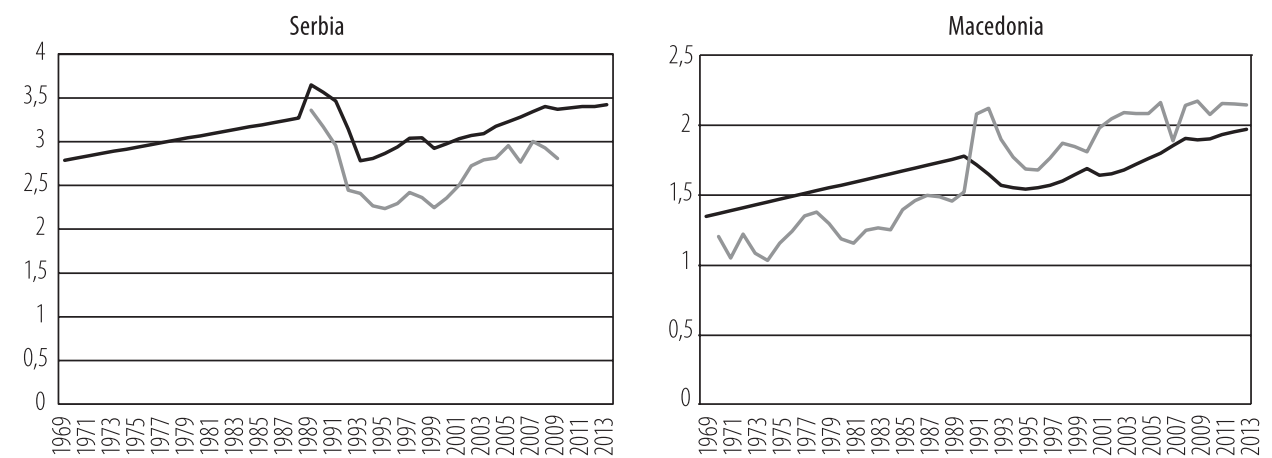

- loggdpit naturaloutput

— loggdpit naturaloutput 


\section{References}

1. Apostolov, M. (2011). "Governance and Enterprise Restructuring: The Case of Macedonia.” Transition Studies Review 18(2): 299-309.

2. Barro, R. J. (1976). "Perceived Wealth in Bonds and Social Security and the Ricardian Equivalence Theorem: Reply to Feldstein and Buchanan.” Journal of Political Economy 84(2): 343-349.

3. Bergman, M. (2001). "Testing government solvency and the No Ponzi Game condition.” Applied Economics Letters 8(1): 27-29.

4. Besimi, F., G. T. Pugh, et al. (2006). “The Monetary Transmission Mechanism in Macedonia: Implications for Monetary Policy." Centre for Research on Emerging Economies Working Paper No. 02-2006.

5. Bićanić, I., J. Kukavčić, et al. (2010). “The post recession growth prospects of south east European economies.” Southeastern Europe 34(2): 193 - 230.

6. Bitzenis, A. and E. Nito (2005). "Obstacles to entrepreneurship in a transition business environment: the case of Albania." Journal of Small Business and Enterprise Development 12(4): 564-578.

7. Buchanan, J. M. (1976). "Barro on the Ricardian Equivalence Theorem." Journal of Political Economy 84(2): 337-342.

8. Dell'Anno, R. and M. Piirisild (2007). "Measuring the Non-observed Economy in a Transition Economy: The Case of Bosnia-Herzegovina." Comparative Economic Studies 49(4): 609-631.

9. Egger, P. (2002). "An Econometric View on the Estimation of Gravity Models and the Calculation of Trade Potentials." World Economy 25(2): 297-312.

10. Gros, D. (2002). “The euro for the Balkans?” Economics of Transition 10(2): 491-511.

11. Korovilas, J. P. (1999). “The Albanian Economy in Transition: The Role of Remittances and Pyramid Investment Schemes." Post-Communist Economies 11(3): 399-415.

12. Petkovski, M. and T. Slaveski (1997). "Foreign Trade in the Republic of Macedonia.” Eastern European Economics 35(1): 52-75.

13. Romer, D. (2006). Advanced macroeconomics, McGraw-Hill.

14. Romer, D. H. (2000). "Keynesian Macroeconomics without the LM Curve." Journal of Economic Perspectives 14(2): 149-169.

15. Schmitt-Grohé, S. and M. n. Uribe (2003). "Closing small open economy models.” Journal of International Economics 61(1): 163-185.

16. Seater, J. J. (1993). “Ricardian Equivalence.” Journal of Economic Literature 31(1): 142-190. 
17. Shijaku, G. and A. Gjokuta (2013). "Fiscal policy and economic growth: the case of Albania." Bank of Albania.

18. Slaveski, T. (1997). "Privatization in the Republic of Macedonia: Five Years After." Eastern European Economics 35(1): 31-51.

19. Snowdon, B. and H. R. Vane (2005). Modern Macroeconomics: Its Origins, Development and Current State, E. Elgar.

20. Staikouras, C., E. Mamatzakis, et al. (2008). «Cost efficiency of the banking industry in the South Eastern European region.» Journal of International Financial Markets, Institutions and Money 18(5): 483-497.

21. Tamegawa, K. (2013). "How does the no-Ponzi game condition work in an optimal consumption problem?” Economics \& Finance Research 1(1): 42-44.

22. Taylor, J. B. (1993). "Discretion versus policy rules in practice." CarnegieRochester Conference Series on Public Policy 39(0): 195-214.

23. Taylor, J. B. (2000). "Reassessing Discretionary Fiscal Policy.” Journal of Economic Perspectives 14(3): 21-36.

24. Taylor, J. B. (2001). "The Role of the Exchange Rate in Monetary-Policy Rules." American Economic Review 91(2): 263-267.

25. Thomas, M. and V. Bojicic-Dzelilovic (2014). Public Policy Making in the Western Balkans: Case Studies of Selected Economic and Social Policy Reforms, Springer Netherlands.

26. Vika, I. and E. Luçi (2011). The Equilibrium Real Exchange Rate of Lek Vis-à-vis Euro?: Is it Much Misaligned? Athens, Bank of Greece discussion papers 